\title{
An Account Analysis Of PCAOB Inspection Reports For Triennially-Inspected Audit Firms
}

Mark Landis, San Francisco State University, USA

Scott I. Jerris, San Francisco State University, USA

Mike Braswell, San Francisco State University, USA

\begin{abstract}
Since 2005, the PCAOB (Public Company Accounting Oversight Board) has been issuing inspection reports for triennially-inspected audit firms as part of its overall mission to improve audit quality. This study analyzes the findings in the PCAOB inspection reports by classifying the audit deficiencies cited in the reports by area of deficiency and type of audit failure. CPA firms can utilize these findings in their efforts to reduce client engagement audit risk. The results indicate that the overall number of cited deficiencies is declining each year, revenue and asset accounts are the most frequently cited accounts, business combinations and equity transactions are the most cited transactions, and insufficient testing or documentation is the primary type of audit failure. We also document that most departures from GAAP occur in the accounting for business transactions or in liability accounts.
\end{abstract}

Keywords: audit; PCAOB; auditor oversight; account analysis

\section{INTRODUCTION AND MOTIVATION}

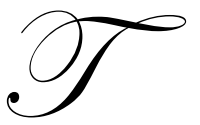

he first PCAOB inspection reports were issued in 2005 with the stated goal of increasing audit quality. However, while a growing body of research links PCAOB inspection reports to other measures of audit quality (e.g., Gunny and Zhang 2009) or the public's reaction to PCAOB reports (e.g., Lennox and Pittman 2010), relatively little research has been conducted on the actual findings reported in the inspection reports themselves. Analysis of the deficiencies most frequently cited by the PCAOB is important if inspection reports are to serve as a guide for audit firms to minimize audit risk and improve audit quality. To that end, this study presents descriptive analyses of the accounts and transactions cited in the PCAOB inspection reports for triennially-inspected ${ }^{1}$ audit firms.

Because triennial firms are smaller firms, they have more opportunity to improve audit quality. Research has shown that larger auditors (and particularly Big 4 auditors) have lower thresholds for issuing modified reports, are more able to restrict earnings management behaviors, and are sanctioned less by the Securities and Exchange Commission. All of these are indications that larger firms provide higher quality audits to preserve their reputation or defend against costly litigation (Francis 2004). The reports of the PCAOB inspections of triennial firms can yield valuable insights into the specific areas of smaller firm audits that need the most improvement and thereby assist those firms in improving audit quality.

Only three other published studies to our knowledge have reported account and transaction analyses of inspection reports. Roybark (2006) compares triennial firm and annual firm inspection reports issued by the PCAOB in 2005 and documents the types of deficiencies found on the inspection reports, but does tabulate the

\footnotetext{
${ }^{1}$ Firms with over 100 issuer clients are inspected annually by the PCAOB and are referred to as "annual" firms. Firms with less than 100 issuer clients are inspected once every three years and are referred to as "triennial" firms.
} 
frequencies of deficiencies. Gramling and Watson (2009) analyze the inspection reports of the largest twenty triennial firms, but they do not tabulate the frequencies of the deficiencies either. Hermanson et al. (2007) examine triennial firm inspection reports issued in 2005 and 2006, the first two years of the PCAOB inspections. They find that inadequate testing or documentation is the most common audit failure, and that revenue accounts and receivable accounts were most likely to have deficiencies. However, they do not document which account deficiencies are most associated with which types of failures. The PCAOB also issued a report summarizing its observations for triennial inspections between 2004 and 2006 (PCAOB 2007b).

Since 2006, the PCAOB has begun publicly criticizing auditors for conducting too much work rather than not enough work (Palmrose 2006; Glover et al. 2009), and so the reports analyzed by Roybark (2006) and Hermanson et al. (2007) may reflect different areas of deficiencies than newer reports as a consequence of this shift in philosophy. This study examines all PCAOB inspections reports issued between 2005 and 2008. Thus, in addition to documenting areas of deficiencies on triennial firm inspections, our expanded sample also allows us to examine the potential effects of this new philosophy.

\section{RESEARCH METHOD}

We examined 770 PCAOB inspection reports of triennially-inspected firms issued between 2005 and 2008. Of these, 339 reports had deficiencies. We coded each deficiency on those reports, and each deficiency had two parts: the area of the deficiency, and the type of audit failure that the auditor had committed.

\section{Areas of Deficiencies}

We identified five general areas of deficiencies. The first area is account deficiencies; these refer to improper audit procedures that affected a specific account such as revenues or loan loss reserves. Occasionally, the PCAOB inspectors would identify two accounts for the same deficiency in which case we would classify the deficiency by our judgment of the primary reason for the deficiency (for example, if the PCAOB cited "revenues and the related liabilities", we would code it as a revenue deficiency). We categorized the various accounts by account type for additional analyses. Account types are assets, equity, expenses, income / revenues, liabilities, and reserves. Reserves are isolated from other assets because of the attention they have received by regulators and researchers when analyzing or discussing earnings management (Levitt 1998; Nelson et al. 2002); more earnings management is generally considered to be one indicator of poor audit quality (Francis 2004). All identified accounts and their account type are listed in Appendix 1.

The second area of deficiency relates to audit procedures performed by the audit firm. Audit procedure deficiencies are generally deficiencies in the types of tests used by auditors (e.g., analytical procedures, use of third parties) or the conclusions reached by auditors (e.g., going concern reports, discrepancies in the financial statements and audit work papers). The third area of deficiency is overall financial statements. Overall financial statement deficiencies are those deficiencies in which the PCAOB inspectors do not cite specific accounts but instead cite general errors for a certain financial statement such as the balance sheet or income statement; these errors are broader in nature than account-specific or transaction-specific deficiencies. The fourth area of deficiency, systems deficiencies, refers to deficiencies in internal control testing or electronic data processing testing. Finally, the fifth area of deficiency is transaction deficiencies which refer to problems in testing specific business events or exchanges. All identified transaction deficiencies are listed in Appendix 2.

\section{Types of Failures}

We identified three general types of failures. Pervasive audit failures are usually noted by the PCAOB as such; these indicate substantial failures by the auditor to follow GAAS. They also include the failure to modify a financial statement after an error was detected, or if an auditor performs insufficient work to be considered the primary auditor. Departures from GAAP occur when the PCAOB determines that an account balance or transaction treatment is not recorded in accordance with GAAP. We consider both pervasive audit failures and departures from GAAP to be "severe" audit failures. Inadequate test failures refer to failure by the audit firm to either perform sufficient tests or to document those tests in the workpapers; these are the least severe and most common type of failure. 


\section{RESULTS}

Table 1 summarizes the number of PCAOB inspection reports issued for triennial firms by year. Beginning in 2007, the PCAOB started issuing the second inspection report for some firms, and we analyze those reports separately from the first inspection reports issued for audit firms. Panel A shows an overall declining trend in the number of deficiencies found on each report. While the second-report firms have very few deficiencies per report $(0$ in 2007 and 0.2 in 2008, on average), the trend also holds for first-report firms. This trend may reflect a shift in inspection philosophy that occurred in May 2005 (which would not be reflected in most inspection reports until 2007) in which the PCAOB moved from criticizing audit firms for not doing enough work to doing too much auditing (Palmrose 2006; Glover et al. 2009). Along these lines, Panel A also indicates the highest number of deficiencies reported on inspection reports were found in the year 2006 as the average number of deficiencies was 1.9 deficiencies per report. However, we note these trends may also reflect improving audit quality in response to PCAOB inspections.

Table 1: Number of Deficiencies by Firm Report

\begin{tabular}{|c|c|c|c|c|c|}
\hline \multicolumn{6}{|c|}{ Panel A: Number of deficiencies by first- and second-report firms } \\
\hline & 2005 & 2006 & 2007 & 2008 & Total \\
\hline No. of first reports & 166 & 198 & 152 & 113 & 629 \\
\hline No. of deficiencies & 287 & 379 & 149 & 174 & 989 \\
\hline Deficiencies per report & 1.7 & 1.9 & 1.0 & 1.5 & 1.6 \\
\hline No. of second reports & 0 & 0 & 6 & 135 & 141 \\
\hline No. of deficiencies & 0 & 0 & 0 & 26 & 26 \\
\hline Deficiencies per report & -- & -- & 0 & 0.2 & 0.2 \\
\hline Total reports & 166 & 198 & 158 & 248 & 770 \\
\hline Total deficiencies & 287 & 379 & 149 & 200 & 1015 \\
\hline Deficiencies per report & 1.7 & 1.9 & 0.9 & 0.8 & 1.3 \\
\hline \multicolumn{6}{|c|}{ Panel B: Number of firms with deficiencies by first- and second-report firms } \\
\hline & 2005 & 2006 & 2007 & 2008 & Total \\
\hline \multicolumn{6}{|l|}{ First-report firms } \\
\hline With deficiencies & 77 & 136 & 61 & 57 & 331 \\
\hline Percent & $46 \%$ & $69 \%$ & $40 \%$ & $50 \%$ & $53 \%$ \\
\hline Without deficiencies & 89 & 62 & 91 & 56 & 298 \\
\hline Percent & $54 \%$ & $31 \%$ & $60 \%$ & $50 \%$ & $47 \%$ \\
\hline Total first reports & 166 & 198 & 152 & 113 & 629 \\
\hline \multicolumn{6}{|l|}{ Second-report firms } \\
\hline With deficiencies & 0 & 0 & 0 & 8 & 8 \\
\hline Percent & -- & -- & $0 \%$ & $6 \%$ & $6 \%$ \\
\hline Without deficiencies & 0 & 0 & 6 & 127 & 133 \\
\hline Percent & -- & -- & $100 \%$ & $94 \%$ & $94 \%$ \\
\hline Total second reports & 0 & 0 & 6 & 135 & 141 \\
\hline
\end{tabular}

Panel B of Table 1 shows the number of first- and second-report firms containing audit deficiencies. The results of this analysis indicate two major findings: first, roughly half of the first-report firms (53 percent) have deficiencies, but firms greatly improve their performance for their second inspection report as only 6 percent of second-report firms had deficiencies. Second, first-report firms in 2007 and 2008 were not able to "learn" enough from reports issued for other audit firms in 2005 and 2006 that they were able to avoid deficiencies altogether. Fifty percent of first-report firms still had deficiencies in 2008, and the overall trend for first-report firms is noticeably trending downward. Clearly, though, audit firms learn from their own inspections.

Table 2, Panel A shows the areas of deficiencies by year. The table indicates that account deficiencies comprise 60 percent of the deficiencies. However, the percentage of transaction deficiencies appears to be trending 
slightly upward in recent years. We expect to observe this trend over time because audit firms are able to establish procedures for examining specific accounts, but due to the unique nature of transactions, audit procedures or controls may not be in place to ensure the transactions are properly audited. As such, this increasing proportion of transaction deficiencies appears to support the argument that PCAOB inspections increase audit quality.

Table 2: Number of Deficiencies by Area and Failure Type

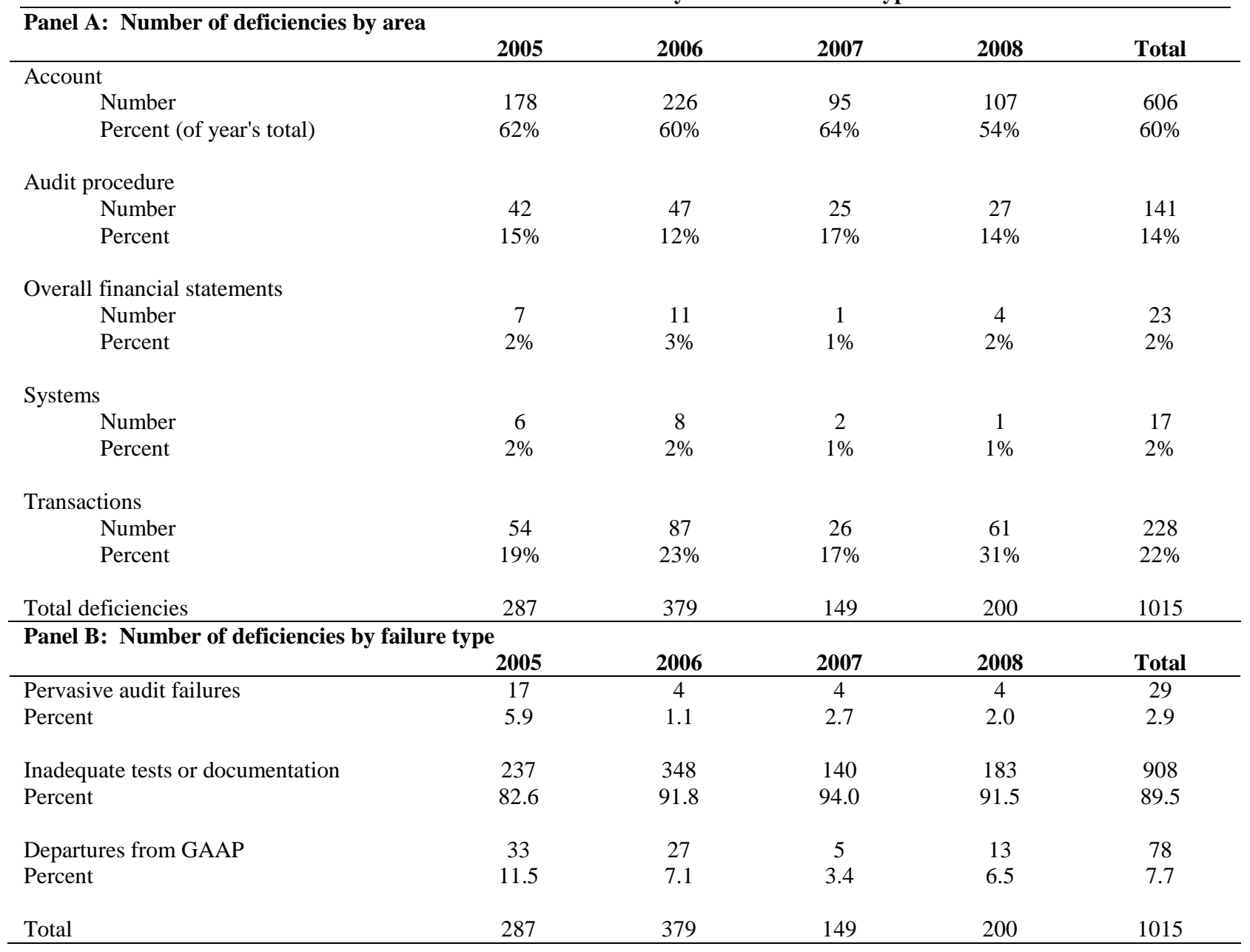

Panel B of Table 2 tabulates the deficiencies by type of audit procedure failure. The vast majority, just under 90 percent of deficiencies, relate to inadequate audit testing procedures or the documentation of those tests. Departures from GAAP are the second most frequent failure, and pervasive audit failures are third. Panel B indicates that a substantial number of departures from GAAP and pervasive audit failures were reported in 2005, the first year of inspection reports, and the numbers have since been steadily trending downward. This finding suggests that audit quality is improving over time, though it may also reflect a shift in the PCAOB inspection philosophy.

We next analyze the trends in specific accounts that were cited in the inspections in Table 3. While overall account deficiencies are decreasing as previously discussed, in recent years, income and revenue accounts constitute a rising proportion of deficiencies. However, asset accounts still comprise the plurality of account deficiencies (39 percent), followed by income and revenue accounts ( 21 percent), and reserve accounts (13 percent).

Table 3: Account Deficiencies by Year

\begin{tabular}{llllll}
\hline 2005 & 2006 & 2007 & 2008 & Total \\
\hline 14
\end{tabular}




\begin{tabular}{|c|c|c|c|c|c|c|}
\hline \multicolumn{7}{|l|}{ Asset } \\
\hline & Number & 78 & 82 & 36 & 38 & 234 \\
\hline & Percent & $44 \%$ & $36 \%$ & $38 \%$ & $36 \%$ & $39 \%$ \\
\hline \multicolumn{7}{|c|}{ Equity } \\
\hline & Number & 10 & 26 & 8 & 10 & 54 \\
\hline & Percent & $6 \%$ & $12 \%$ & $8 \%$ & $9 \%$ & $9 \%$ \\
\hline \multicolumn{7}{|c|}{ Expense } \\
\hline & Number & 18 & 7 & 7 & 3 & 35 \\
\hline & Percent & $10 \%$ & $3 \%$ & $7 \%$ & $3 \%$ & $6 \%$ \\
\hline \multicolumn{7}{|c|}{ Income / revenue } \\
\hline & Number & 30 & 39 & 29 & 28 & 126 \\
\hline & Percent & $17 \%$ & $17 \%$ & $31 \%$ & $26 \%$ & $21 \%$ \\
\hline \multicolumn{7}{|c|}{ Liability } \\
\hline & Number & 30 & 23 & 6 & 18 & 77 \\
\hline & Percent & $17 \%$ & $10 \%$ & $6 \%$ & $17 \%$ & $13 \%$ \\
\hline \multicolumn{7}{|c|}{ Reserve } \\
\hline & Number & 12 & 49 & 9 & 10 & 80 \\
\hline & Percent & $7 \%$ & $22 \%$ & $9 \%$ & $9 \%$ & $13 \%$ \\
\hline Total & & 178 & 226 & 95 & 107 & 606 \\
\hline
\end{tabular}

Table 4 separates the account deficiencies by account type and audit failure type. In Panel A, the asset accounts are analyzed, and the findings show that the most common asset accounts with audit deficiencies are intangible assets and inventory. While most of the inventory account deficiencies relate to inadequate audit testing, the intangible asset values deviated from GAAP on three occasions. Still, the vast majority of audit failures for intangible assets (and assets in general) relate to inadequate testing or documentation of audit tests.

Panel B shows analysis of income and revenue accounts, and revenue is the overall most frequently-cited account with 93 percent of audit deficiencies. Most of the revenue failures are inadequate tests or documentations. Panel C, showing the liability account analysis, indicates that departures from GAAP account for over 19 percent (or 15/77) of the deficiencies; of all account types, this is by far the highest percentage. The PCAOB attributed most deficiencies to liabilities in general without identifying a specific liability account, though convertible debt also accounted for 31 percent of the deficiencies. Finally, Panel D of Table 4 analyzes the reserve accounts and indicates that the loan loss reserve account suffered the most audit deficiencies; all were attributable to insufficient testing. Interestingly, despite the role of reserves in contributing to earnings management (Nelson et al. 2002), the PCAOB did not find any departures from GAAP in reserve accounts. Findings for equity or expense accounts were not tabled because of the relatively small number of deficiencies reported for those account types; however, findings for those accounts are listed in Appendix 1.

Transaction deficiencies are analyzed in Table 5. Business combinations were found to contain the most deficiencies, including failures resulting from inadequate testing and departures from GAAP, as well as the only pervasive audit failure related to transactions. Departures from GAAP accounted for almost 13 percent of the total transaction-based deficiencies, which is the next highest concentration of departures from GAAP after liability accounts. The PCAOB found many deficiencies in general equity transactions, stock-based compensation, and sale of stock, indicating that equity transactions represent a troublesome area for triennial audit firms.

Finally, we analyze audit procedures in Table 6. Two primary findings emerge from this table. First, auditors did not adequately test the work of external parties. The use of service or third party auditors accounted for 30 percent of the audit procedure deficiencies; most of these related to auditors failing to properly test the work of the service or third party auditors. In five cases, overreliance on these auditors was so severe that the PCAOB declared these to be pervasive audit failures. In addition to the work of service or third party auditors, the work of specialists also appeared not to be adequately tested as specialists (other than loan review specialists) accounted for another 20 percent of the total deficiencies. Overreliance on service auditors, third party auditors, or specialists can increase liability exposure to audit firms, so these findings may be of particular interest to audit firms. The second major finding is that on 18 occasions, the PCAOB declared the overall audits to suffer pervasive audit failures, and on an additional 12 occasions, the PCAOB cited the overall audit as suffering from inadequate audit tests or documentation. 
Table 4: Deficiencies by Account Type

Panel A: Asset accounts

\begin{tabular}{|c|c|c|c|c|c|}
\hline Asset account & $\begin{array}{c}\text { Pervasive } \\
\text { audit failures }\end{array}$ & $\begin{array}{c}\text { Inadequate } \\
\text { audit tests }\end{array}$ & $\begin{array}{l}\text { Departures } \\
\text { from GAAP }\end{array}$ & $\begin{array}{c}\text { Total } \\
\text { Deficiencies }\end{array}$ & Percent \\
\hline Intangible asset value & & 46 & 3 & 49 & 20.9 \\
\hline Inventory & & 40 & & 40 & 17.1 \\
\hline Marketable securities & & 34 & 3 & 37 & 15.8 \\
\hline Accounts receivable & & 30 & & 30 & 12.8 \\
\hline Asset valuation & & 16 & 3 & 19 & 8.1 \\
\hline Net deferred tax assets & & 13 & & 13 & 5.6 \\
\hline Leases and rental property & & 11 & & 11 & 4.7 \\
\hline Notes receivable & & 9 & & 9 & 3.8 \\
\hline Property, plant, \& equipment & & 8 & & 8 & 3.4 \\
\hline Real estate investments & & 5 & & 5 & 2.1 \\
\hline All others & & 13 & & 13 & 5.6 \\
\hline Total asset deficiencies & 0 & 225 & 9 & 234 & 100.0 \\
\hline \multicolumn{6}{|c|}{ Panel B: Income / Revenue accounts } \\
\hline Income / revenue account & $\begin{array}{c}\text { Pervasive } \\
\text { audit failures }\end{array}$ & $\begin{array}{c}\text { Inadequate } \\
\text { audit tests }\end{array}$ & $\begin{array}{l}\text { Departures } \\
\text { from GAAP }\end{array}$ & $\begin{array}{c}\text { Total } \\
\text { Deficiencies } \\
\end{array}$ & Percent \\
\hline Revenue & 1 & 114 & 2 & 117 & 92.9 \\
\hline Interest income & & 4 & & 4 & 3.2 \\
\hline Royalties & & 2 & & 2 & 1.6 \\
\hline Other income & & 1 & & 1 & 0.8 \\
\hline Intercompany revenues & & & 1 & 1 & 0.8 \\
\hline Investment income & & 1 & & 1 & 0.8 \\
\hline
\end{tabular}

Total income / revenue

\begin{tabular}{|c|c|c|c|c|c|}
\hline deficiencies & 1 & 122 & 3 & 126 & 100.0 \\
\hline \multicolumn{6}{|l|}{ Panel C: Liability accounts } \\
\hline Liability account & $\begin{array}{c}\text { Pervasive } \\
\text { audit failures }\end{array}$ & $\begin{array}{c}\text { Inadequate } \\
\text { audit tests }\end{array}$ & $\begin{array}{l}\text { Departures } \\
\text { from GAAP }\end{array}$ & $\begin{array}{c}\text { Total } \\
\text { Deficiencies }\end{array}$ & Percent \\
\hline Liabilities (general) & & 24 & 6 & 30 & 39.0 \\
\hline Convertible debt & & 21 & 3 & 24 & 31.2 \\
\hline Notes payable & & 3 & 2 & 5 & 6.5 \\
\hline Deferred expenses & & 3 & 1 & 4 & 5.2 \\
\hline Accounts payable & & 3 & & 3 & 3.9 \\
\hline Long-term debt & & 2 & & 2 & 2.6 \\
\hline Taxes payable & & 1 & 1 & 2 & 2.6 \\
\hline Due-on-demand line of credit & & & 2 & 2 & 2.6 \\
\hline Unearned revenue & & 1 & & 1 & 1.3 \\
\hline Interest payable & & 1 & & 1 & 1.3 \\
\hline All others & & 3 & & 3 & 3.9 \\
\hline
\end{tabular}

Total liability deficiencies

$0 \quad 62$

15

77

100.0

\begin{tabular}{|c|c|c|c|c|c|}
\hline Reserve account & $\begin{array}{c}\text { Pervasive } \\
\text { audit failures }\end{array}$ & $\begin{array}{c}\text { Inadequate } \\
\text { audit tests }\end{array}$ & $\begin{array}{l}\text { Departures } \\
\text { from GAAP }\end{array}$ & $\begin{array}{c}\text { Total } \\
\text { Deficiencies }\end{array}$ & Percent \\
\hline Loan loss reserve & & 49 & & 49 & 61.3 \\
\hline Allowance for doubtful accounts & & 16 & & 16 & 20.0 \\
\hline Inventory obsolescence reserve & & 7 & & 7 & 8.8 \\
\hline Pension & & 4 & & 4 & 5.0 \\
\hline Insurance reserve & & 2 & & 2 & 2.5 \\
\hline Policy and claim reserves & & 1 & & 1 & 1.3 \\
\hline Income tax valuation allowance & & 1 & & 1 & 1.3 \\
\hline Total reserve deficiencies & 0 & 80 & 0 & 80 & 100.0 \\
\hline \multicolumn{6}{|c|}{ Table 5: Deficiencies by Transaction } \\
\hline & Pervasive & Inadequate & Departures & Total & \\
\hline 16 & & & & (C) $2011 \mathrm{~T}$ & ite Inst \\
\hline
\end{tabular}




\begin{tabular}{|c|c|c|c|c|c|}
\hline Transaction & audit failures & audit tests & from GAAP & Deficiencies & Percent \\
\hline Business combinations & 1 & 41 & 8 & 50 & 21.9 \\
\hline Stock-based compensation & & 25 & 2 & 27 & 11.8 \\
\hline Related party transactions & & 25 & 1 & 26 & 11.4 \\
\hline Equity transactions & & 22 & 1 & 23 & 10.1 \\
\hline Software expense and capitalization & & 12 & 1 & 13 & 5.7 \\
\hline Contingency & & 11 & 1 & 12 & 5.3 \\
\hline Sale of stock & & 8 & 3 & 11 & 4.8 \\
\hline Discontinued operations & & 4 & 3 & 7 & 3.1 \\
\hline Financing transaction & & 4 & 2 & 6 & 2.6 \\
\hline Litigation - current and settlements & & 2 & 2 & 4 & 1.8 \\
\hline Asset retirement obligation & & 3 & 1 & 4 & 1.8 \\
\hline Contracts and implications & & 4 & & 4 & 1.8 \\
\hline Subsequent event disclosure & & 4 & & 4 & 1.8 \\
\hline Joint venture & & 4 & & 4 & 1.8 \\
\hline Purchase transactions & & 3 & & 3 & 1.3 \\
\hline Loan covenant compliance & & 2 & & 2 & 0.9 \\
\hline Environmental remedial obligations & & 2 & & 2 & 0.9 \\
\hline Compensation - accrued & & 2 & & 2 & 0.9 \\
\hline Derivatives & & 2 & & 2 & 0.9 \\
\hline All others & & 18 & 4 & 22 & 9.6 \\
\hline Total transaction deficiencies & 1 & 198 & 29 & 228 & 100.0 \\
\hline
\end{tabular}

Table 6: Deficiencies by Audit Procedure

\begin{tabular}{|c|c|c|c|c|c|}
\hline Audit procedure & $\begin{array}{c}\text { Pervasive } \\
\text { audit failures }\end{array}$ & $\begin{array}{c}\text { Inadequate } \\
\text { audit tests }\end{array}$ & $\begin{array}{c}\text { Departures } \\
\text { from GAAP }\end{array}$ & $\begin{array}{c}\text { Total } \\
\text { Deficiencies }\end{array}$ & Percent \\
\hline Service auditor or Third party auditor & 5 & 38 & & 43 & 30.3 \\
\hline Audit - overall & 18 & 12 & 2 & 32 & 22.5 \\
\hline Use of specialist & & 29 & & 29 & 20.4 \\
\hline Going concern opinion & 2 & 19 & & 21 & 14.8 \\
\hline Service organization & & 6 & & 6 & 4.2 \\
\hline Cut-off testing & & 4 & & 4 & 2.8 \\
\hline Materiality threshold & & 3 & & 3 & 2.1 \\
\hline Auditor workpaper discrepancies & 1 & & & 1 & 0.7 \\
\hline Loan review specialist & & 1 & & 1 & 0.7 \\
\hline Fraud potential & & 1 & & 1 & 0.7 \\
\hline Analytical procedures & & 1 & & 1 & 0.7 \\
\hline Total audit procedure deficiencies & 26 & 113 & 2 & 142 & 100.0 \\
\hline
\end{tabular}

In addition to these two main findings, two other findings are noteworthy. First, despite the report issued in 2007 by the PCAOB which criticized audit firms for failing to conduct the required SAS 99 brainstorming sessions in assessing fraud potential (PCAOB 2007a), the PCAOB only cited one firm for inadequate audit testing in relation to fraud potential. Second, going concern testing accounts for 21 deficiencies, including two pervasive audit failures, which represents a large percentage of total audit procedure deficiencies (almost 15 percent).

\section{CONCLUSION}

This study provides descriptive statistics of the areas of deficiencies and types of audit failures reported on triennial PCAOB inspection reports. Several findings are noteworthy. First, the overall trend of deficiencies reported by the PCAOB is decreasing, which is consistent with two different arguments put forth by researchers that either the PCAOB inspection reports improve audit quality or that a shift in the PCAOB inspection philosophy is resulting in fewer reported deficiencies. Future research may attempt to parse these arguments. Second, revenue is the most frequently-cited account, but assets, as a whole, are responsible for most account deficiencies. Third, most departures from GAAP occur in liability accounts and transactions. Fourth, equity-related transactions are a 
major source of transaction deficiencies, and inadequate tests of third party auditors are a major source of audit procedure deficiencies. Finally, the vast majority of deficiencies that the PCAOB report are related to inadequate audit testing or the documentation of those tests.

These findings may be useful to practitioners for a variety of reasons. Auditors may use these to anticipate likely areas of detection risk on future audits, or they may use these findings to examine their current competencies on commonly-cited areas of deficiency. For example, equity-related transactions may be an important topic for auditors' CPE training, or auditors may wish to obtain education on the latest workpaper documentation requirements. These findings may also be important to academic researchers. The declining trend in PCAOB deficiencies, both in overall deficiencies and severe deficiencies, suggests that the inspection report date may be an important variable in statistical models. Also, despite academic findings citing reserves and revenue as common areas for earnings management (Nelson et al. 2002), our findings indicate that the PCAOB did not identify any severe deficiencies in reserve accounts and only two in revenue accounts. To the extent that measures of earnings management rely on reserve and revenue accounts (see, for example, Stubben 2010), associations between these measures and severe deficiencies in PCAOB inspections (e.g., Gunny and Zhang 2009) may be caused by other variables within the earnings management measures or from other sources.

As regulators, courts, congressional leaders, scholars, and practitioners continue to debate the role and scope of the PCAOB, it is important to know the type of findings that have been reported on one of the PCAOB's most important disclosures - its inspection reports. Additionally, if the PCAOB is to improve audit quality, it is also important that the inspection reports be analyzed in a manner that facilitates the identification of common problem areas of audits. The findings in this study aim to contribute to both of those discussions.

\section{AUTHOR INFORMATION}

Mark Landis is an assistant professor at San Francisco State University. His areas of expertise include information systems, group decision making, and auditor decision making.

Scott I. Jerris is a professor at San Francisco State University. His areas of expertise are capital markets and financial statement analysis.

Mike Braswell is an assistant professor at San Francisco State University. His areas of expertise include corporate governance and financial statement quality.

\section{REFERENCES}

1. $\quad$ Francis, J. R. 2004. What do we know about audit quality? The British Accounting Review 36 (4):345-368.

2. Glover, S. M., D. F. Prawitt, and M. H. Taylor. 2009. Audit standard setting and inspection for U.S. public companies: A critical assessment and recommendations for fundamental change. Accounting Horizons 23 (2):221-237.

3. Gramling, A. A., and M. G. Watson. 2009. Analysis of peer review reports: A focus on deficiencies of the Top 20 triennially inspected firms. Current Issues in Auditing 3 (2):A1-A14.

4. Gunny, K., and T. Zhang. 2009. PCAOB inspection reports and audit quality. Working paper, University of Colorado.

5. Hermanson, D. R., R. W. Houston, and J. C. Rice. 2007. PCAOB inspections of smaller CPA Firms: Initial evidence from inspection reports. Accounting Horizons 21 (2):137-152.

6. Lennox, C., and J. Pittman. 2010. Auditing the auditors: Evidence on the recent reforms to the external monitoring of audit firms. Journal of Accounting and Economics 49 (1-2):84-103.

7. Levitt, A. 1998. The Numbers Game. Remarks of SEC Chairman A. Levitt at the New York University Center for Law and Business: New York, NY.

8. Nelson, M. W., J. A. Elliott, and R. L. Tarpley. 2002. Evidence from auditors about managers' and auditors' earnings management decisions. The Accounting Review 77 (Supplement):175-202. 
9. Palmrose, Z. 2006. Maintaining the value and viability of auditors as gatekeepers under SOX: An auditing master proposal. In Financial Gatekeepers: Can They Protect Investors?, edited by Y. Fuchita and R. E. Litan. Baltimore, MD: The Brookings Institute, 103-135.

10. Public Company Accounting Oversight Board (PCAOB). 2007a. Observations on auditors' implementation of PCAOB standards relating to auditors' responsibilities with respect to fraud. Washington D.C., 1-14.

11. 2007b. Report on the PCAOB'S 2004, 2005, and 2006 inspections of domestic triennially inspected firms. Washington, D.C.:1-20.

12. Roybark, H. M. 2006. An analysis of audit deficiencies based on PCAOB inspection reports issued during 2005. Journal of Accounting, Ethics \& Public Policy 6 (2):125-154.

13. Stubben, S. R. 2010. Discretionary revenues as a measure of earnings management. Accounting Review 85 (2):695-717. 


\section{APPENDIX 1}

Account Classifications

\begin{tabular}{|c|c|c|c|}
\hline 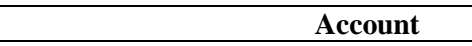 & Account Type & Total deficiencies & Percent \\
\hline Accounts payable & Liability & 3 & 0.5 \\
\hline Accounts receivable & Asset & 30 & 5.0 \\
\hline Allowance for doubtful accounts & Reserve & 16 & 2.6 \\
\hline Asset valuation & Asset & 19 & 3.1 \\
\hline Cash & Asset & 2 & 0.3 \\
\hline Commission expense & Expense & 1 & 0.2 \\
\hline Common and preferred stock & Equity & 18 & 3.0 \\
\hline Consulting expense & Expense & 2 & 0.3 \\
\hline Convertible debt & Liability & 24 & 4.0 \\
\hline Cost of goods sold / services provided & Expense & 1 & 0.2 \\
\hline Deferred compensation & Liability & 1 & 0.2 \\
\hline Deferred expenses & Liability & 4 & 0.7 \\
\hline Deferred revenue & Asset & 3 & 0.5 \\
\hline Depreciation expense & Expense & 1 & 0.2 \\
\hline Diluted EPS & Equity & 6 & 1.0 \\
\hline Due-on-demand line of credit & Liability & 2 & 0.3 \\
\hline Equity & Equity & 20 & 3.3 \\
\hline Expenses (in general) & Expense & 14 & 2.3 \\
\hline Extraordinary loss & Expense & 1 & 0.2 \\
\hline Foreign currency translation & Expense & 1 & 0.2 \\
\hline Income tax expense & Expense & 1 & 0.2 \\
\hline Income tax valuation allowance & Reserve & 1 & 0.2 \\
\hline Insurance reserve & Reserve & 2 & 0.3 \\
\hline Intangible asset value & Asset & 49 & 8.1 \\
\hline Intercompany revenues & Income / Revenue & 1 & 0.2 \\
\hline Interest income & Income / Revenue & 4 & 0.7 \\
\hline Interest payable & Liability & 1 & 0.2 \\
\hline Inventory & Asset & 40 & 6.6 \\
\hline Inventory obsolescence reserve & Reserve & 7 & 1.2 \\
\hline Investment income & Income / Revenue & 1 & 0.2 \\
\hline Leases and rental property & Asset & 11 & 1.8 \\
\hline Liabilities & Liability & 30 & 5.0 \\
\hline Loan loss reserve & Reserve & 49 & 8.1 \\
\hline Loans receivable & Asset & 4 & 0.7 \\
\hline Long-term debt & Liability & 2 & 0.3 \\
\hline Marketable securities & Asset & 37 & 6.1 \\
\hline Natural resource valuation and costs & Asset & 1 & 0.2 \\
\hline Net deferred tax assets & Asset & 13 & 2.1 \\
\hline Notes payable & Liability & 5 & 0.8 \\
\hline Notes receivable & Asset & 9 & 1.5 \\
\hline Other income & Income / Revenue & 1 & 0.2 \\
\hline Payroll expense & Expense & 5 & 0.8 \\
\hline Payroll taxes - accrued & Liability & 1 & 0.2 \\
\hline Pension & Reserve & 4 & 0.7 \\
\hline Policy and claim reserves & Reserve & 1 & 0.2 \\
\hline Prepaid assets & Asset & 1 & 0.2 \\
\hline Prepaid expenses & Asset & 2 & 0.3 \\
\hline Property, plant, \& equipment & Asset & 8 & 1.3 \\
\hline Real estate investments & Asset & 5 & 0.8 \\
\hline Research \& development costs & Expense & 5 & 0.8 \\
\hline Revenue & Income / Revenue & 117 & 19.3 \\
\hline Royalties & Income / Revenue & 2 & 0.3 \\
\hline Salary and wage expense & Expense & 3 & 0.5 \\
\hline Taxes payable & Liability & 2 & 0.3 \\
\hline Unearned revenue & Liability & 1 & 0.2 \\
\hline Unpaid losses & Liability & 1 & 0.2 \\
\hline Warrants & Equity & 10 & 1.7 \\
\hline Total & & 606 & 100.0 \\
\hline
\end{tabular}




\section{APPENDIX 2}

\section{List of Transactions}

\begin{tabular}{|c|c|c|}
\hline Transaction & Total deficiencies & Percent \\
\hline Asset retirement obligation & 4 & 1.8 \\
\hline Business combinations & 50 & 21.9 \\
\hline Capitalized licenses & 1 & 0.4 \\
\hline Compensation - accrued & 2 & 0.9 \\
\hline Compensation and loans - officers & 1 & 0.4 \\
\hline Contingency & 12 & 5.3 \\
\hline Contracts and implications & 4 & 1.8 \\
\hline Debt covenant violation & 1 & 0.4 \\
\hline Debt extinguishment & 2 & 0.9 \\
\hline Debt maturities & 1 & 0.4 \\
\hline Debt restructuring & 1 & 0.4 \\
\hline Derivatives & 2 & 0.9 \\
\hline Discontinued operations & 7 & 3.1 \\
\hline Environmental remedial obligations & 2 & 0.9 \\
\hline Equity transactions & 23 & 10.1 \\
\hline Financing transaction & 6 & 2.6 \\
\hline Gain from pension curtailment & 1 & 0.4 \\
\hline Gain on sale of asset & 1 & 0.4 \\
\hline Hedge contracts & 1 & 0.4 \\
\hline Joint venture & 4 & 1.8 \\
\hline Litigation - current and settlements & 4 & 1.8 \\
\hline Loan acquisition costs & 1 & 0.4 \\
\hline Loan covenant compliance & 2 & 0.9 \\
\hline Mortgage securitization & 1 & 0.4 \\
\hline Nonmonetary exchanges & 2 & 0.9 \\
\hline Oil and gas accounting & 1 & 0.4 \\
\hline Proceeds from government grants & 1 & 0.4 \\
\hline Purchase options & 1 & 0.4 \\
\hline Purchase transactions & 3 & 1.3 \\
\hline Related entity investment & 1 & 0.4 \\
\hline Related party transactions & 26 & 11.4 \\
\hline Reverse acquisitions & 1 & 0.4 \\
\hline Sale of real estate & 1 & 0.4 \\
\hline Sale of stock & 11 & 4.8 \\
\hline Software expense and capitalization & 13 & 5.7 \\
\hline Stock-based compensation & 27 & 11.8 \\
\hline Stock-debt exchange & 1 & 0.4 \\
\hline Subsequent event disclosure & 4 & 1.8 \\
\hline Vendor rebates & 1 & 0.4 \\
\hline Total & 228 & 100.0 \\
\hline
\end{tabular}


Journal of Business \& Economics Research-March, 2011 Volume 9, Number 3 NOTES 